\title{
Persepsi Dan Harapan Mahasiswa Terhadap Ketersediaan E-Journal Di Perpustakaan Fakultas Peternakan Universitas Jambi
}

\author{
Ade Novia Maulana ${ }^{1}$, Zarfina Yenti ${ }^{2}$, Barkah Dwi Saputri ${ }^{3}$, Jam'ah Alfi Hidayah ${ }^{4}$ \\ Universitas Islam Negeri Sulthan Thaha Saifuddin Jambi \\ ${ }^{1}$ Jalan Jambi - Muaro Bulian Km.16, Muaro Jambi, 36363 \\ e-mail:ade@uinjambi.ac.id ${ }^{l}$
}

\begin{abstract}
Intoduction. This research will discuss about students' perceptions and expectations of the availability of e-journals in the animal husbandry faculty library Universitas Jambi.

Data collection method. In this study will use a method that is quantitative. Data collection methods use are questionnaires, observation, interviews, and documentation.

Analysis data. This is the questionnaire in the study will use a likert scale. The population in this study amounted to 265 students and the sample used was 73 respondents. In the sample technique, the research will use a random sampling technique or random sample.

Result and discussion. Then the 8 indicators of perception, and the average result show that the score is in good category with each indicator's score, namely acceptance $(2,62)$, evaluation $(2,73)$, ease of access(2,8), diversity of e-journals(2,15), utilization (2,56), access (2,96), cost (2,57), and recency $(1,83)$. As for the results of the study will show that the score on the overall perception and also the expectations of students in the availability of e-journals in the animal husbandry faculty library Universitas Jambi is 20,22:8=2,52 on the scale 2,51-3,27.

Conclusions. So, it can concluded that the overall perceptions and expectations of students in the availability of e-journals in the animal husbandry faculty library Universitas Jambiare good.
\end{abstract}

Key words: perception, libray, Students

\begin{abstract}
ABSTRAK
Pendahuluan. Penelitian ini akan membahas tentang persepsi dan juga harapan mahasiswa terhadap adanya ketersediaan e-journal di Perpustakaan Fakultas Peternakan Universitas Jambi.

Metode pengumpulan data. Pada penelitian ini akan menggunakan sebuah metode yaitu kuantitatif. Metode pengumpulan data yang digunakan yaitu metode kuesioner, observasi, wawancara dan juga dokumentasi. Hal ini Angket pada penelitian akan menggunakan skala likert. Populasi pada penelitian ini berjumlah 265 mahasiswa dan juga sampel digunakan berjumlah 73 responden.

Analisis data. Pada teknik sampel penelitian akan menggunakan sebuah teknik random sampling atau juga sampel acak.

Hasil dan Pembahasan. Maka, dalam 8 indikator persepsi, dan hasil rata-rata menunjukkan bahwa skor dalam kategori baik dengan skor masing-masing indikator yaitu Penerimaan (2,62), Evaluasi/Penilaian (2,73), Kemudahan Akses (2,8), Keragaman E-Journal (2,15), Pemanfaatan (2,56), Pengaksesan (2,96), Biaya (2,57), dan Kebaruan (1,83). Adapun dari hasil penelitian akan menunjukkan dari skor pada keseluruhan persepsi dan juga harapan mahasiswa dalam ketersediaan ejournal di Perpustakaan Fakultas Peternakan Universitas Jambi adalah 20,22:8 = 2,52 yang berada pada skala 2,51- 3,27.

Kesimpulan. Sehingga, bisa disimpulkan bahwa pada keseluruhan persepsi dan juga harapan mahasiswa dalam ketersediaan e-journal di Perpustakaan Fakultas Peternakan Universitas Jambi adalah Baik

Kata Kunci: Persepsi, e-journal, library, students
\end{abstract}




\section{A. PENDAHULUAN}

Adanya suatu perkembangan pada teknologi informasi dan juga komunikasi saat ini telah memberikan banyak dampak besar bagi berbagai bidang kehidupan, hal ini tak terkecuali pada bidang perpustakaan. Dengan adanya perkembangan teknologi informasi dan juga komunikasi hal ini mampu mengubah pola pencarian suatu informasi (PNRI, 2007: 210).

Perpustakaan perguruan tinggi dalam buku pedoman perpustakaan perguruan tinggi merupakan unsur penunjang tri dharma perguruan tinggi yang mempunyai beberapa fungsi yaitu edukasi, sumber informasi, penunjang riset, rekreasi, publikasi, deposit dan interpretasi informasi (DEPDIKNAS, 2004:58). Salah satu aspek penting yang membuat perpustakaan banyak diminati atau dimanfaatkan adalah ketersediaan koleksi yang berkualitas. Karena itu tugas utama setiap perpustakaan adalah membangun koleksi yang kuat untuk kepentingan penggunanya. Koleksi perpustakaan merupakan aset yang sangat penting dan menyediakan koleksi yang memadai baik dari segi kualitas, kuantitas, jenis dan ragam yang sesuai dengan kebutuhan pengguna sehingga koleksi perpustakaan dapat dimanfaatkan secara efektif dan efisien. E-journal merupakan salah satu terbitan berseri yang menyajikan informasi terkini yang berkaitan hasil penelitian terbaru. Menurut kamus kepustakawanan Indonesia e-journal adalah jurnal yang segala aspek (penyimpanan, review, penerbitan, dan penyebaran) dilakukan secara elektronik (Lasa, 2009: 128).

Persepsi dalam filosofi adalah sejauh mana unsur- unsur sensorik seperti suara, aroma dan warna dan dalam realitas objektif, bukan dalam pikiran perseptor (Richard, 1987: 598601). Sejak individu dilahirkan, sejak itu pula individu secara langsung berhubungan dengan dunia luarnya dan menerima stimulus atau rangsangan dari luar disamping dari dalam dirinya sendiri dengan menggunakan alat inderanya. Melalui stimulus yang diterimanya, individu akan mengalami persepsi (Adhitama, 2016:7). Persepsi menurut Kamus Bahasa Indonesia adalah tanggapan langsung terhadap sesuatu (Riwayadi \& Anisyah, 2010:5). Menurut Leavi persepsi memiliki dua arti secara sempit dan secara luas. Secara sempit persepsi berarti penglihatan dan bagaimana orang melihat sesuatu sedangkan dalam arti luas persepsi pandangan atau pengertian bagaimana seseorang memandang dan mengartikan sesuatu. Dari definisi tersebut dapat disimpulkan bahwa persepsi merupakan usaha untuk mengartikan sesuatu berdasarkan sudut pandang orang tersebut. Faktor yang 
mempengaruhi persepsi seseorang terhadap e- journal adalah pengetahuannya terhadap teknologi, kepuasan mahasiswa terhadap e-journal, usaha perpustakaan dalam memuaskan kebutuhan informasi mahasiswanya sebagai pemustaka.

Berdasarkan Kamus Besar Bahasa Indonesia, harapan adalah keinginan supaya menjadi kenyataan. Berdasarkan Ensiklopedia Indonesia edisi khusus, harapan merupakan antisipasi atau peramalan dari kejadian di masa yang akan datang berdasarkan pada pengalaman yang lalu dan stimulus pada saat sekarang (Harwati, 2010: 5). Mahasiswa mempunyai peranan penting dalam mewujudkan cita-cita pembangunan nasional, sementara itu perguruan tinggi merupakan lembaga pendidikan yang secara formal diserahi tugas dan tanggung jawab mempersiapkan mahasiswa sesuai dengan tujuan pendidikan tinggi. Tujuan pendidikan tinggi dapat tercapai apabila Tridharma perguruan tinggi dapat terlaksana, yaitu mampu menyelenggarakan pendidikan, melakukan penelitian dan melakukan pengabdian pada masyarakat. E- journal adalah jurnal yang segala aspek (penyiapan, review, penerbitan dan penyebaran) dilakukan secara elektronik. Kemuculan jurnal ini karena mahalnya pencetakan jurnal, kemajuan teknologi komputer dan meluasnya world wide web. E-journal memiliki beberapa kelebihan bila dibanding dengan jurnal tercetak antara lain: kemutakhiran, cepat diterima, menghemat tempat, dalam waktu yang sama dapat diakses banyak orang, lebih aman, mudah penelusuran, dan relatif lebih murah (Surianti, 2016:14)

Peneliti menilai bahwa sumber informasi yang tersedia pada e-journal Fakultas Peternakan Universitas Jambi yang tersedia pada portal sudah cukup lengkap untuk dijadikan sebagai sumber referensi dalam penulisan karya ilmiah atau dalam pembuatan tugas kuliah. E-journal yang terdapat dalam portal; yang telah disediakan menurut saya kurang menarik untuk digunakan karena tampilannya pun masih sederhana dan juga artikel yang disediakan belum cukup memadai untuk membantu mahasiswa dalam menyelesaikan tugas kuliah mereka. Berdasarkan hasil observasi peneliti di Fakultas Peternakan bahwa beberapa mahasiswa masih jarang mengakses layanan e-journal sebagai sumber rujukan mereka, sebagian mahasiswa belum terbiasa menggunakan layanan e-journal tersebut sebagai sumber rujukan dalam penulisan karya ilmiah ataupun dalam pembuatan tugas kuliah bahkan masih terdapat mahasiswa yang tidak mengetahui adanya layanan e-journal tersebut, seharusnya dengan adanya layanan e-journal memudahkan mahasiswa dalam 
penelusuran informasi atau sebagai sumber rujukan mereka dalam pembuatan tugas kuliah. Hal ini dikarenakan pihak pengelola e-journal tidak peduli dengan mahasiswa yang akan mencari sumber informasi, pihak pengelola hanya berfokus kepada apa yang akan mereka sajikan padahal masih banyak mahasiswa yang tidak tertarik untuk menggunakan e-journal yang disediakan

\section{B. METODE PENELITIAN}

Dalam penelitian ini, peneliti menggunakan jenis penelitian deskriptif dengan pendekatan kuantitatif yaitu metode penelitian yang dilandaskan pada filsafat positivisme, digunakan untuk meneliti pada populasi atau sampel tertentu. Pendekatan kuantitatif dipilih karena pendekatan ini merupakan salah satu jenis penelitian yang sistematis, terencana dan terstruktur sejak awal hingga pembuatan desain penelitian. 38 Variabel penelitian ini diukur menggunakan satu variabel yaitu persepsi mahasiswa terhadap ketersediaan koleksi ejournal pada Perpustakaan Fakultas Peternakan. Populasi dari penelitian ini adalah mahasiswa Fakultas Peternakan Universitas Jambi angkatan tahun 2017 yang berjumlah 265 orang. Pengambilan sampel yang digunakan dalam penelitian ini adalah random sampling. Jadi sampel yang akan diteliti oleh peneliti adalah 73 orang. Sampel yang diinginkan oleh peneliti adalah mahasiswa/i di Perpustakaan Fakultas Peternakan Universitas Jambi angkatan tahun 2017 dan tidak memandang Jenis kelamin, Jurusan. Dari jumlah populasi 265 orang maka diperoleh sampel adalah 73 orang.

Penulis memilih tempat atau lokasi penelitian ini di Perpustakaan Fakultas Peternakan Universitas Jambiyang beralamat di Kampus Pinang Masak, Jl. Raya Jambi Muara Bulian Km.15 Mendalo Indah. penelitian dalam kurun waktu 5 minggu pengumpulan data dan 1,5 bulan pengolahan data meliputi penyajian data dalam bentuk tabel. Adapun metode pengumpulan data pada penelitian ini yaitu kusioner, observasi, wawncara dan dokumentasi. Dalam hal ini maka analisis data yang dilakukan dengan cara statistik deskriptif melalui mengedit data, memasukkan data, memberikan kode dan juga tabulasi. Data primer yang diperoleh dalam penelitian ini adalahhasil observasi dari kuesioner kepada mahasiswa sedangkan data sekunder yang diperoleh adalah berupa buku, laporan ataupun dokumen lain yang berhubungan dengan masalah peneitian. Adapun yang menjadi sumber data dalam penelitian ini adalah Mahasiswa semester 6 (enam). 


\section{HASIL DAN PEMBAHASAN}

1. Persepsi Terhadap Indikator Penerimaan

Tabel 1. Persepsi Terhadap Indikator Penerimaan

\begin{tabular}{|c|l|c|c|}
\hline No & \multicolumn{1}{|c|}{ Pernyataan } & Jawaban & Skor \\
\hline 1 & $\begin{array}{l}\text { Saya menerima tema berbagai e- } \\
\text { journal yang } \\
\text { disediakan }\end{array}$ & $\begin{array}{c}\text { Kurang } \\
\text { baik }\end{array}$ & 2,09 \\
\hline 2 & $\begin{array}{l}\text { Ketika saya melakukan pencarian pada e- } \\
\text { joural, proses penerimaan data yang } \\
\text { didapat untuk mendapatkan } \\
\text { informasi sangat cepat }\end{array}$ & Sangat baik & 3,16 \\
\hline \multicolumn{2}{c}{$\Sigma 5,25: 2=2,62$ (Baik) } & \\
\hline
\end{tabular}

Berdasarkan tabel di atas dapat diketahui hasil skor rata- rata yaitu 2,62. Skor ini berada pada titik 2,52 - 3,27. Dengan demikian dapat disimpulkan bahwa persepsi mahasiswa terhadap ketersediaan koleksi e-journal pada Perpustakaan Fakultas Peternakan Universitas Jambi untuk indikator Penerimaan adalah Baik.

2. Persepsi Terhadap Indikator Evaluasi

Tabel 2. Persepsi Terhadap Indikator Evaluasi

\begin{tabular}{llcc}
\hline No & \multicolumn{1}{c}{ Pernyataan } & Jawaban & Skor \\
\hline 1 & $\begin{array}{l}\text { Jumlah artikel yang dimuat pada portal } \\
\text { sudah memadai }\end{array}$ & Kurang baik & 2,94 \\
\hline 2 & $\begin{array}{l}\text { Saya menilai kualitas e-journal yang } \\
\text { disediakan sudah baik }\end{array}$ & baik & 3,09 \\
\hline 3 & $\begin{array}{l}\text { Saya menilai informasi yang } \\
\text { dibutuhkan sulit untuk ditemukan }\end{array}$ & $\begin{array}{l}\text { Sangat tidak } \\
\text { baik }\end{array}$ & 1,12 \\
\hline 4 & $\begin{array}{l}\text { Saya menilai e-journal tidak ada } \\
\text { gunanya }\end{array}$ & $\begin{array}{l}\text { Sangat baik } \\
\text { E-journal memiliki nilai dan berdaya } \\
\text { guna tinggi bagi Mahasiswa }\end{array}$ & 3,82 \\
\hline
\end{tabular}

$$
\Sigma 13,68: 5=2,73 \text { (Baik) }
$$

Menur

ut persepsi mahasiswa terhadap ketersediaan koleksi E-journal pada Perpustakaan Fakultas Peternakan Universitas Jambi dalam indikator evaluasi/penilaian adalah Baik. Hal ini dapat dilihat skor rata-rata dari setiap pernyataan jawaban mendapat jawaban baik pada indikator ini. Berdasarkan tabel di atas dapat diketahui hasil skor rata- rata yaitu 2,73. Skor ini berada pada titik2,52 - 3,27. Dengan demikian dapat disimpulkan bahwa persepsi mahasiswa terhadap ketersediaan koleksi e-journal pada Perpustakaan Fakultas Peternakan Universitas Jambi untuk indikator evaluasi/penilaian adalah Baik. 
3. Persepsi Terhadap Indikator Kemudahan Akses

Tabel 3. Persepsi Terhadap Indikator kemudahan akses

\begin{tabular}{llcc}
\hline No & \multicolumn{1}{c}{ Pernyataan } & Jawaban & skor \\
\hline 1 & $\begin{array}{l}\text { Tidak terdapat kendala ketika saya } \\
\text { mengakses informasi yang saya butuhkan }\end{array}$ & $\begin{array}{c}\text { Kurang } \\
\text { baik }\end{array}$ & 2,15 \\
\hline 2 & $\begin{array}{l}\text { Bahasa informasi yang disajikan pada e-journal } \\
\text { yang saya akses mudah untuk dimengerti }\end{array}$ & Baik & 3,02 \\
\hline 3 & $\begin{array}{l}\text { E-journal dapat diakses oleh siapa saja dalam } \\
\text { waktu } \\
\text { yang bersamaan }\end{array}$ & Sangat baik & 2,68 \\
\hline 4 & $\begin{array}{l}\text { Walaupun aliran listrik sedang padam, tetapi saya } \\
\text { masih bisa mengakses e-journal }\end{array}$ & Baik & 2,93 \\
\hline
\end{tabular}

Menurut persepsi mahasiswa terhadap ketersediaan koleksi E-journal pada Perpustakaan Fakultas Peternakan Universitas Jambi dalam indikator kemudahan akses adalah Kurang Baik. Hal ini dapat dilihat dari jawaban para responden dengan tiga pernyataan mahasiswa menjawab setuju. Berdasarkan tabel di atas dapat diketahui hasil skor rata- rata yaitu 2,8. Skor ini berada pada titik1,76 - 2,51. Dengan demikian dapat disimpulkan bahwa persepsi mahasiswa terhadap ketersediaan koleksi e-journal pada Perpustakaan Fakultas Peternakan Universitas Jambi untuk indikator kemudahan akses adalah Kurang Baik.

4. Persepsi Terhadap Indikator Keragaman e-Journal

Tabel 4. Persepsi Terhadap Indikator Keragaman e-Journal

\begin{tabular}{|c|c|c|c|}
\hline No & Pernyataan & Jawaban & Skor \\
\hline 1 & $\begin{array}{l}\text { Adanya berbagai macam tema e- journal yang } \\
\text { menarik untuk dibaca }\end{array}$ & Kurang baik & 2,13 \\
\hline 2 & $\begin{array}{l}\text { Saya dapat dengan mudah mengerjakan tugas kuliah } \\
\text { karena terdapat berbagai macam tema artikel yang } \\
\text { sesuai dengan } \\
\text { jurusan yang ada di Fakultas Peternakan }\end{array}$ & Kurang baik & 2,36 \\
\hline 3 & $\begin{array}{l}\text { Adanya keragaman jenis artikel yang dapat } \\
\text { dijadikan referensi dalam } \\
\text { membuat tugas kuliah }\end{array}$ & Kurang baik & 1,97 \\
\hline \multicolumn{2}{|r|}{$\Sigma 6,46: 3=2,15$ (Kurang Baik) } & & \\
\hline
\end{tabular}

Perpustakaan Fakultas Peternakan Universitas Jambi dalam indikator keragaman e-journal adalah Kurang Baik. Hal ini dapat dilihat dari ketiga pernyataan yang peneliti berikan dan semua responden menjawab tidak setuju. Berdasarkan tabel di atas dapat diketahui hasil skor rata- rata yaitu 2,15. Skor ini berada pada titik1,76 - 2,51. Dengan demikian dapat disimpulkan bahwa persepsi mahasiswa terhadap ketersediaan koleksi e-journal pada Perpustakaan Fakultas Peternakan Universitas Jambi untuk indikator keragaman e-journal 
adalah Kurang Baik

5. Persepsi Terhadap Indikator Pemanfaatan

Tabel. 5 Persepsi Terhadap Indikator Pemanfaatan

\begin{tabular}{|c|c|c|c|}
\hline No & Pernyataan & Jawaban & Skor \\
\hline 1 & $\begin{array}{l}\text { Dalam memanfaatkan e- journal saya selalu } \\
\text { memahami bahasa } \\
\text { yang digunakan }\end{array}$ & Baik & 2,83 \\
\hline 2 & $\begin{array}{l}\text { Saya lebih sering memanfaatkan e- journal } \\
\text { dibandingkan harus membeli buku }\end{array}$ & Baik & 3,09 \\
\hline 3 & $\begin{array}{l}\text { Kebutuhan informasi memotivasi saya untuk } \\
\text { memanfaatkan koleksi e-journal }\end{array}$ & Kurang baik & 2,36 \\
\hline 4 & $\begin{array}{l}\text { Teman berperan dalam membangun motivasi } \\
\text { saya untuk memanfaatkan } \\
\text { koleksi e-journal }\end{array}$ & Kurang baik & 2,26 \\
\hline 5 & $\begin{array}{l}\text { Dosen berperan dalam membangun motivasi saya } \\
\text { untuk } \\
\text { memanfaatkan koleksi e-journal }\end{array}$ & Kurang baik & 2,27 \\
\hline
\end{tabular}

Menurut persepsi mahasiswa terhadap ketersediaan koleksi E-journal pada Perpustakaan

Fakultas Peternakan Universitas Jambi dalam indikator pemanfaatan adalah Baik.

Berdasarkan tabel di atas dapat diketahui hasil skor rata- rata yaitu 2,56. Skor ini berada pada titik2,52 - 3,27. Dengan demikian dapat disimpulkan bahwa persepsi mahasiswa terhadap ketersediaan koleksi e-journal pada Perpustakaan Fakultas Peternakan Universitas Jambi untuk indikator pemanfaatan adalah Baik.

6. Persepsi Terhadap Indikator Pengaksesan

Tabel. 6 Persepsi terhadap Indikator Pengaksesan

\begin{tabular}{llcc}
\hline No & \multicolumn{1}{c}{ Pernyataan } & Jawaban & skor \\
\hline 1 & $\begin{array}{l}\text { Tidak terdapat kendala ketika saya } \\
\text { mengakses informasi yang saya butuhkan }\end{array}$ & $\begin{array}{c}\text { Kurang } \\
\text { baik }\end{array}$ & 2,15 \\
\hline 2 & $\begin{array}{l}\text { Bahasa informasi yang disajikan pada e- } \\
\text { journal yang saya akses mudah untuk } \\
\text { dimengerti }\end{array}$ & Baik & 3,02 \\
\hline 3 & $\begin{array}{l}\text { E-journal dapat diakses oleh siapa saja } \\
\text { dalam waktu } \\
\text { yang bersamaan }\end{array}$ & Sangat baik & 2,68 \\
\hline 4 & $\begin{array}{l}\text { Walaupun aliran listrik sedang padam, } \\
\text { tetapi saya masih bisa mengakses e- } \\
\text { journal } \\
\text { yang saya inginkan }\end{array}$ & Baik & 2,93 \\
\hline 5 & $\begin{array}{l}\text { Tidak membutuhkan waktu yang lama } \\
\text { dalam mengakses e- journal yang saya } \\
\text { inginkan }\end{array}$ & Baik & 3,06 \\
\hline
\end{tabular}

Menurut persepsi mahasiswa terhadap ketersediaan koleksi E-journal pada

Perpustakaan Fakultas Peternakan Universitas Jambi dalam indikator pengaksesan adalah 
Baik. Berdasarkan tabel di atas dapat diketahui hasil skor rata- rata yaitu 2,96. Skor ini berada pada titik2,52 - 3,27. Dengan demikian dapat disimpulkan bahwa persepsi mahasiswa terhadap ketersediaan koleksi e-journal pada Perpustakaan Fakultas Peternakan Universitas Jambi untuk indikator pengaksesan adalah Baik.

\section{Persepsi Terhadap Indikator Biaya}

Tabel 7. Persepsi terhadap indicator biaya

\begin{tabular}{llcc}
\hline No & \multicolumn{1}{c}{ Pernyataan } & Jawaban & Skor \\
\hline 1 & $\begin{array}{l}\text { Dalam menggunakan e- journal, biaya yang } \\
\text { saya butuhkan relatif lebih murah }\end{array}$ & Baik & 2,73 \\
\hline 2 & $\begin{array}{l}\text { Saya selalu dimintai biaya saat mengakses e-journal } \\
\text { yang saya butuhkan }\end{array}$ & $\begin{array}{c}\text { Kurang } \\
\text { baik }\end{array}$ & 1,76 \\
\hline 3 & $\begin{array}{l}\text { Tidak membutuhkan biaya karena tidak perlu } \\
\text { mencetak e- journal yang saya butuhkan }\end{array}$ & Baik & 2,46 \\
\hline 4 & $\begin{array}{l}\text { Saya memilih untuk membeli data internet agar dapat } \\
\text { digunakan untuk mendownload koleksi e-journal } \\
\text { daripada harus } \\
\text { membeli buku }\end{array}$ & Sangat baik & 3,34 \\
\hline
\end{tabular}

$\Sigma 10,29: 4=2,57$ (Baik)

Menurut persepsi mahasiswa terhadap ketersediaan koleksi E-journal pada

Perpustakaan Fakultas Peternakan Universitas Jambi dalam indikator biaya adalah Baik. Hal ini dapat dilihat dari skor rata-rata dari pernyataan mendapat jawaban baik. Berdasarkan tabel di atas dapat diketahui hasil

skor rata- rata yaitu 2,57. Skor ini berada pada titik2,52-3,27. Dengan demikian dapat disimpulkan bahwa persepsi mahasiswa terhadap ketersediaan koleksi e-journal pada Perpustakaan Fakultas Peternakan Universitas Jambi untuk indikator biaya adalah Baik.

8. Persepsi Terhadap Indikator Kebaruan

Tabel 8. Persepsi Terhadap Indikator Kebaruan

\begin{tabular}{l|l|c|c}
\hline No & \multicolumn{1}{|c|}{ Pernyataan } & Jawaban & Skor \\
\hline 1 & $\begin{array}{l}\text { Selalu ada artikel baru pada portal yang } \\
\text { dapat saya gunakan }\end{array}$ & $\begin{array}{c}\text { Kurang } \\
\text { baik }\end{array}$ & 1,87 \\
\hline 2 & $\begin{array}{l}\text { Saya dapat dengan mudah menemukan topik } \\
\text { yang sesuai dengan kebutuhan } \\
\text { untuk menyelesaikan tugas kuliah }\end{array}$ & $\begin{array}{c}\text { Sangat tidak } \\
\text { baik }\end{array}$ & 1,72 \\
\hline 3 & E-journal yang tersedia selalu up to date & $\begin{array}{c}\text { Kurang } \\
\text { baik }\end{array}$ & 1,91 \\
\hline \multicolumn{2}{c}{$\Sigma 5,5: 3=1,83$ (Kurang Baik) } & &
\end{tabular}

Menurut persepsi mahasiswa terhadap ketersediaan koleksi E-journal pada Perpustakaan Fakultas Peternakan Universitas Jambi dalam indikator kebaruan adalah Kurang Baik. Hal 
ini dapat dilihat dari skor rata-rata pernyataan diatas adalah kurang baik. Berdasarkan tabel di atas dapat diketahui hasil skor rata- rata yaitu 1,83. Skor ini berada pada titik1,76-2,51. Dengan demikian dapat disimpulkan bahwa persepsi mahasiswa terhadap ketersediaan koleksi e-journal pada Perpustakaan Fakultas Peternakan Universitas Jambi untuk indikator kebaruan adalah Kurang Baik.

9. Rekapitulasi Skor Persepsi dan Harapan Mahasiswa Terhadap Ketersediaan e-Journal di Perpustakaan Fakultas Peternakan Universitas Jambi

Tabel 9. Rekapitulasi Skor Persepsi dan harapan mahasiswa terhadap Ketersediaan e-Journal

\begin{tabular}{l|lc|c}
\hline No & \multicolumn{1}{|c|}{ Indikator } & Jawaban & Skor \\
\hline 1 & Penerimaan & Baik & 2,62 \\
\hline 2 & Evaluasi/ penilaian & Baik & 2,73 \\
\hline 3 & Kemudahan akses & Kurang baik & 2,8 \\
\hline 4 & $\begin{array}{l}\text { Keragaman e- } \\
\text { journal }\end{array}$ & Kurang baik & 2,15 \\
& Bemanfaatan & Baik & 2,56 \\
\hline 5 & Pengaksesan & Baik & 2,96 \\
\hline 7 & Biaya & Baik & 2,57 \\
\hline 8 & Kebaruan & Kurang Baik & 1,83 \\
\hline \multicolumn{4}{l}{$\Sigma 20,22: 8=2,52$ (Baik) } \\
\hline
\end{tabular}

Hasil penelitian menunjukkan bahwa skor keseluruhan persepsi dan harapan mahasiswa terhadap ketersediaan koleksi e-journal pada Perpustakaan Fakultas Peternakan Universitas Jambi adalah $20,22: 8=2,52$. Hal ini yang berada pada skala interval 2,52 - 3,27. Maka dapat disimpulkan bahawa persepsi mahasiswa terhadap e-journal pada Perpustakaan Fakultas Peternakan Universitas Jambi adalah Baik.

\section{KESIMPULAN}

Adapun kesimpulan dari penelitian ini yaitu, bahwa pada penelitian yang dilakukan terhadap e- journal pada Perpustakaan Fakultas Peternakan Universitas Jambi dapat dinilai Baik, hal ini berdasarkan rata-rata tertinggi yang telah diperoleh dari jawaban para responden terhadap jawaban dari 8 indikator yaitu 2,52 yang telah berada pada skala interval 2,52 - 3,27. Untuk lebih rincinya sebagai berikut: pada indikator penerimaan, maka persepsi mahasiswa dalam ketersediaan koleksi e-journal pada Perpustakaan Fakultas Peternakan Universitas Jambi dalam kategori indikator penerimaan adalah Baik dengan skor 2,62 dengan jumlah dua pernyataan yang mencakup sub indikator 
ketersediaan koleksi e-journal. Indikator evaluasi/penilaian, maka persepsi mahasiswa terhadap ketersediaan koleksi e-journal pada Perpustakaan Fakultas Peternakan Universitas Jambi dalam kategori indikator evaluasi/penilaian adalah Baik dengan skor 2,73 dengan jumlah lima pernyataan yang mencakup sub indikator ketersediaan koleksi ejournal. Indikator kemudahan akses, maka persepsi mahasiswa terhadap ketersediaan koleksi e-journal pada Perpustakaan Fakultas Peternakan Universitas Jambi dalam kategori indikator penerimaan adalah Kurang Baik dengan skor 2,8 dengan jumlah tiga pernyataan yang mencakup sub indikator ketersediaan koleksi e- journal. Indikator keragaman E-Journal, maka persepsi mahasiswa terhadap ketersediaan koleksi e- journal pada Perpustakaan Fakultas Peternakan Universitas Jambi dalam kategori indikator keragaman e-journal adalah Kurang Baik dengan skor 2,15 dengan jumlah tiga pernyataan yang mencakup sub indikator ketersediaan koleksi e- journal.

Indikator pemanfaatan, maka persepsi mahasiswa terhadap ketersediaan koleksi ejournal pada Perpustakaan Fakultas Peternakan Universitas Jambi dalam kategori indikator penerimaan adalah Baik dengan skor 2,56 dengan jumlah lima pernyataan yang mencakup sub indikator ketersediaan koleksi e-journal. Indikator pengaksesan, maka persepsi mahasiswa terhadap ketersediaan koleksi e-journal pada Perpustakaan Fakultas Peternakan Universitas Jambi dalam kategori indikator penerimaan adalah Baik dengan skor 2,96 dengan jumlah lima pernyataan yang mencakup sub indikator ketersediaan koleksi e- journal. Indikator biaya, maka persepsi mahasiswa terhadap ketersediaan koleksi e-journal pada Perpustakaan Fakultas Peternakan Universitas Jambi dalam kategori indikator penerimaan adalah Baik dengan skor 2,57 dengan jumlah empat pernyataan yang mencakup sub indikator ketersediaan koleksi e- journal. Indikator kebaruan, maka persepsi mahasiswa terhadap ketersediaan koleksi e-journal pada Perpustakaan Fakultas Peternakan Universitas Jambi dalam kategori indikator penerimaan adalah Kurang Baik dengan skor 1,83 dengan jumlah tiga pernyataan yang mencakup sub indikator ketersediaan koleksi e-journal. 


\section{DAFTAR PUSTAKA}

Adhitama, Wahyu Septyan. (2016). "Persepsi Siswa Kel. s Viii Terhadap Pembelajaran Aktivitas Air Di Smp Negeri 2 Klaten”. Skripsi. Yogyakarta: Universitas Negeri Yogjakarta.

Departemen Pendidikan Nasional. (2004). Perpustakaan Perguruan Tinggi: Buku Pedoman. Jakarta: Direktorat Jenderal Pendidikan Tinggi.

Harwati, Sri. (2010). "Persepsi dan Harapan Pemustaka Terhadap Rencana Perubahan Sistem Perpustakaan Universitas Indonesia”. Skripsi. Depok: Universitas Indonesia.

Perpustakaan Republik Indonesia. (2005). Undang-Undang Republik Indonesia Nomor 43 Tahun 2007 Tentang Perpustakaan. Jakarta: Direktorat Jenderal Pendidikan.

Ricard, Gregory. 1987. Perception In Gregory. Zangwill.

Riwayadi, Susilo \& Suci Nur Anisyah. (2005). Kamus Lengkap Bahasa Indonesia. Surabaya: Sinar Terang.

S.H. Lasa. (2009). Kamus Kepustakawanan Indonesia. Yogyakarta: Pustaka Book Publiser.

Surianti. (2016). "Persepsi Siswa Tentang Ketersediaan Koleksi Di Perpustakaan Sma Muhammadiyah Kalosi Kecamatan Alla Kabupaten Enrekan”, Skripsi. Makassar: UIN Alauddin. 